\title{
Pertumbuhan dan Produksi Tanaman Mentimun terhadap Pemberian Berbagai Takaran Vermikompos pada Tanah Podsolik Merah Kuning
}

\section{(Growth and Yield of Cucumber to Giving Various Vermicompos Dosage on Red Yellow Podsolic Soil)}

\author{
Ahmad Nazarudin'), Mahdiannoor ${ }^{2)}$ \& Zarmiyeni $^{\text {(3) }}$ \\ Program Studi Agroteknologi, Sekolah Tinggi Ilmu Pertanian Amuntai \\ 1)ahmadnazaruddin1@gmail.com \\ ${ }^{2)}$ mahdi_186@yahoo.com \\ ${ }^{3)}$ Zarmiyenilg@yahoo.co.id
}

\begin{abstract}
ABSTRAK
Tanaman mentimun termasuk dalam tumbuhan merambat yang digemari masyarakat luas. Kabupaten Hulu Sungai Tengah didominasi oleh jenis tanah podsolik merah kuning yang mempunyai kendala seperti struktur tanahnya lempung berpasir, permeabilitasnya rendah, aerasi tanah jelek, tanah bereaksi masam, kapasitas menahan air, unsur hara dan kapasitas tukar kation rendah. Usaha yang dapat dilakukan adalah dengan pemberian bahan organik yang dihasilkan dari percampuran antara media cacing tanah dengan kotoran cacing tanah. Tujuan penelitian ini (i) melihat pengaruh pemberian vermikompos dan (ii) mendapatkan takaran terbaik pemberian vermikompos terhadap pertumbuhan dan produksi tanaman mentimun pada tanah podsolik merah kuning. Penelitian ini dilaksanakan di Desa Teluk Mesjid Kecamatan Haruyan Kabupaten Hulu Sungai Tengah Provinsi Kalimantan Selatan. Penelitian ini dilaksanakan pada bulan April-Juni 2015, menggunakan Rancangan Acak Kelompok (RAK) faktor tunggal, dengan 5 taraf perlakuan dan 5 kelompok sehingga terdapat 25 satuan percobaan. Perlakuan yang dicobakan adalah takaran vermikompos yaitu $\left(v_{0}\right) 0$

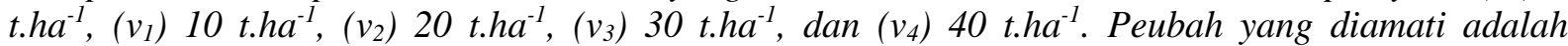
panjang tanaman, jumlah daun, diameter batang, waktu berbunga, jumlah buah dan bobot basah buah pertanaman. Hasil penelitian menunjukan perlakuan berpengaruh nyata terhadap peubah diameter batang umur 21 HST, waktu berbunga, jumlah buah mentimun, dan berpengaruh sangat nyata pada bobot basah buah mentimun tetapi tidak berpengaruh terhadap panjang tanaman umur 7 , 14 dan 21 HST, jumlah daun umur 7, 14 dan 21 HST, diameter batang umur 7 HST dan 14 HST. Perlakuan takaran terbaik vermikompos untuk tanaman mentimun adalah $\left(v_{1}\right) 10$ t.ha ${ }^{-1}$.
\end{abstract}

Kata kunci: Mentimun, vermikompos, podsolik merah kuning, takaran, terbaik.

\section{ABSTRACT}

Cucumber plants, including vines, are popular with the wider community. Hulu Sungai Tengah Regency is dominated by red-yellow podzolic soil types which have problems such as sandy clay soil structure, low permeability, poor soil aeration, acidic reacting soil, water holding capacity, nutrients and low cation exchange capacity. The effort that can be done is by giving organic material produced from a mixture of earthworm media with earthworm feces. The purpose of this study $(i)$ was to see the effect of vermicompost administration and (ii) to get the best dose of vermicompost administration on the growth and production of cucumber plants on red-yellow podzolic soil. This research was conducted in Teluk Mesjid Village, Haruyan District, Hulu Sungai Tengah District, South Kalimantan Province. This research was conducted in April-June 2015, using a single randomized block design (RBD), with five treatment levels and five groups so that there were 25 experimental units. The treatments that were tried were vermicompost doses namely $\left(v_{0}\right) 0$ t.ha $a^{-1},\left(v_{1}\right)$ $10 t \cdot h a^{-1},\left(v_{2}\right) 20$ t.hat $a^{-1}\left(v_{3}\right) 30 t \cdot h a^{-1}$, and $\left(v_{4}\right) 40 t \cdot h a^{-1}$. The variables observed were planting length, number of leaves, stem diameter, flowering time, number of fruits, and wet weight of fruit crops. The results showed the treatment had a significant effect on the stem diameter variable age 21 day after planting (DAP), flowering time, number of cucumber fruit, and had a very significant effect on the cucumber wet weight but did not affect plant length 7, 14 and 21 DAP, number of leaves aged 7, 14 and 21 DAP, stem diameter aged 7 and 14 DAP. The best treatment for vermicompost for cucumber plants is $\left(v_{1}\right) 10$ t.hat. 
Keywords: Cucumber, vermicompost, yellow red podzolic, dosage, best.

\section{PENDAHULUAN}

\section{Tanaman Mentimun (Cucumis} sativus L.) yang termasuk dalam tumbuhan merambat atau merayap ini merupakan salah satu jenis tanaman sayuran buah dari keluarga labu-labuan (Cucurbitaceae) yang sudah sangat populer di seluruh dunia dan digemari masyarakat luas. Menurut sejarah, tanaman mentimun berasal dari benua Asia (Wijoyo, 2012).

Pada umumnya hampir semua jenis tanah yang digunakan untuk lahan pertanian cocok untuk ditanami mentimun. Untuk mendapatkan produksi yang tinggi dan kualitas yang baik, tanaman mentimun membutuhkan tanah yang subur dan gembur, kaya akan bahan organik, tidak tergenang, $\mathrm{pH}$ nya 5-6. Namun masih toleran terhadap $\mathrm{pH} 5,5$ batasan minimal dan $\mathrm{pH} 7,5$ batasan maksimal. Pada $\mathrm{pH}$ tanah kurang dari 5,5 akan terjadi gangguan penyerapan hara oleh akar tanaman sehingga pertumbuhan tanaman terganggu, sedangkan pada tanah yang terlalu basa tanaman akan terserang penyakit klorosis (Rukmana, 1994).

Hasil analisis tanah di Desa Teluk Mesjid Kecamatan Haruyan Kabupaten Hulu Sungai Tengah berdasarkan hasil analisis tanah Laboratorium Balai Penelitian Pertanian Lahan Rawa (Balittra) (2015), dengan $\mathrm{pH} \mathrm{5,} 88$ tergolong agak masam. Untuk kandungan unsur hara $\mathrm{C}$ organik 0, $704 \%$ dan $\mathrm{N}$ total $0,615 \%$ tergolong dalam kriteria sangat rendah. Sedangkan kandungan unsur P dengan 11, $842 \mathrm{ppm} \mathrm{P}$ dan Kdd 0, $139 \mathrm{cmol}(+) / \mathrm{kg}$ termasuk dalam kriteria rendah. Pada kandungan Fe 6, 350 ppm termasuk dalam kriteria sedang.

Tanah podsolik merah kuning memiliki potensi yang tinggi untuk pengembangan pertanian, akan tetapi dalam pemanfaatan tanah podsolik merah kuning ini dihadapkan pada berbagai kendala. Kendala yang sering dijumpai pada tanah podsolik merah kuning adalah struktur tanahnya lempung berpasir, permeabilitasnya rendah, aerasi tanah jelek, tanah bereaksi masam, kapasitas menahan airnya rendah, unsur hara dan kapasitas tukar kation juga sangat rendah. Usaha yang dapat dilakukan adalah dengan pemberian bahan organik pada tanah. Salah satu bahan organik yang dapat diberikan pada tanah adalah pupuk organik yang dihasilkan dari percampuran antara media cacing tanah dengan kotoran cacing tanah (Jamilah, et. al., 2013).

Vermikompos adalah kompos yang dihasilkan dari bahan organik dengan bantuan cacing (vermes). Keuntungan vermikompos adalah prosesnya cepat dan kompos yang dihasilkan (kascing = bekas cacing) mengandung unsur hara tinggi. Vermikompos mengandung berbagai unsur hara yang dibutuhkan tanaman seperti $\mathrm{N}$, $\mathrm{P}, \mathrm{K}, \mathrm{Ca}, \mathrm{Mg}, \mathrm{S}, \mathrm{Fe}, \mathrm{Mn}, \mathrm{Al}, \mathrm{Na}, \mathrm{Cu}, \mathrm{Zn}$, Bo dan Mo tergantung pada bahan yang digunakan. Vermikompos juga dapat membantu proses penghancuran limbah organik (Kusumawati, 2011).

Pemberian vermikompos pada tanah dapat memperbaiki sifat fisik tanah seperti struktur tanah, porositas tanah, permeabilitas dan kemampuan untuk menahan air. Selain itu, vermikompos juga dapat memperbaiki sifat kimia tanah seperti meningkatkan kemampuan menyerap kation sebagai sumber hara mikro dan makro serta meningkatkan $\mathrm{pH}$ pada tanah asam (Mulat, 2003 dalam Ayunita, et. al., 2014).

Hasil penelitian pada tanaman tomat menunjukkan bahwa penambahan vermikompos (kascing) pada 15 t.ha $^{-1}$ berpengaruh nyata meningkatkan total organik tanah, total $\mathrm{N}, \mathrm{P}, \mathrm{K}, \mathrm{Ca}, \mathrm{Zn}$ dan $\mathrm{Mn}$, dibandingkan tanpa vermikompos. Penambahan vermikompos dalam tanah mampu menurunkan $\mathrm{pH}$ tanah. Dengan penambahan vermikompos, komponen fisika tanah seperti struktur dan porositas tanah menjadi lebih baik. Hasil penelitian menunjukkan bahwa penambahan vermikompos berdampak positif terhadap komponen kimia dan fisika tanah (Azarmi, et. al., 2008 dalam Fahrudin, 2009). 
Tujuan penelitian ini (i) melihat pengaruh pemberian vermikompos dan (ii) mendapatkan takaran terbaik pemberian vermikompos terhadap pertumbuhan dan produksi tanaman mentimun pada tanah podsolik merah kuning.

\section{METODE PENELITIAN}

Penelitian ini dilaksanakan di Desa Teluk Mesjid Kecamatan Haruyan Kabupaten Hulu Sungai Tengah pada bulan April sampai Juni 2015. Dengan bahan antara lain lahan podsolik merah kuning, benih mentimun Varietas Metavy, vermikompos sebagai perlakuan penelitian, air dan pestisida nabati. Alat yang digunakan antara lain pulpen, kertas, parang, cangkul, tugal, gembor, hands sprayer, bambu, timbangan, meteran, ember, kamera, gunting, tali dan jangka sorong. Menggunakan Rancangan Acak Kelompok (RAK) faktor tunggal, dengan 5 taraf perlakuan dan 5 kelompok sehingga terdapat 25 satuan percobaan. Perlakuan yang dicobakan adalah takaran vermikompos yaitu $\left(\mathrm{v}_{0}\right) \quad 0$ t.ha $^{-1},\left(\mathrm{v}_{1}\right) \quad 10$ t.ha ${ }^{-1},\left(\mathrm{v}_{2}\right) 20$ t.ha ${ }^{-1},\left(\mathrm{v}_{3}\right) 30$ t.ha-1, dan $\left(\mathrm{v}_{4}\right)$ 40 t.ha ${ }^{-1}$.

Kegiatan yang dilaksanakan mulai dari pengolahan tanah, pemberian perlakuan, penanaman, pemeliharaan, kegiatan pemeliharaan meliputi penyulaman, penyiraman, pengendalian terhadap tumbuhan liar pengganggu, hama dan penyakit. Akhir kegiatan dilapangan adalah pemanenan. Peubah yang diamati adalah panjang tanaman, jumlah daun dan diameter batang umur 7, 14, dan 21 HST; waktu berbunga; jumlah buah dan bobot basah buah pertanaman.

Analisis data dimulai setelah data terkumpul, terlebih dahulu dilakukan uji kehomogenan ragam Bartllet, kemudian untuk mengetahui ada tidaknya pengaruh perlakuan terhadap beberapa takaran vermikompos terhadap pertumbuhan dan produksi tanaman mentimun yang diperoleh dari setiap perlakuan, kemudian dianalisis dengan analisis ragam menggunakan uji - F pada taraf nyata $5 \%$ dan 1\%. Apabila uji - F menunjukan pengaruh nyata atau sangat nyata, dilanjutkan dengan uji Duncan's Multiple Range Test (DMRT) pada taraf 5\% (Hanafiah, 2002).

\section{HASIL DAN PEMBAHASAN}

\section{Hasil}

\section{Panjang Tanaman}

Berdasarkan hasil analisis ragam menunjukkan bahwa pemberian berbagai takaran pupuk vermikompos tidak berpengaruh terhadap panjang tanaman dari umur 7, 14, dan 21 HST.

Hubungan antara pemberian pupuk vermikompos terhadap panjang tanaman umur 7, 14, dan 21 HST disajikan pada Gambar

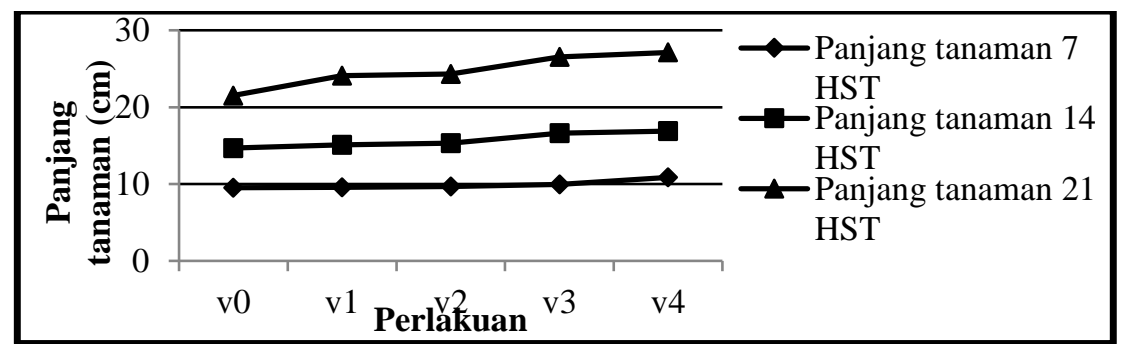

Gambar 1. Grafik hubungan pupuk vermikompos terhadap peningkatan panjang tanaman mentimun umur 7, 14, dan 21 HST.

Dari Gambar 1 dapat dilihat bahwa panjang tanaman umur 7 HST panjang tanaman yang paling rendah terdapat pada perlakuan $\left(\mathrm{v}_{0}\right)$ tanpa perlakuan dengan panjang tanaman $9,52 \mathrm{~cm}$ dan yang paling tinggi berada pada perlakuan (v4) takaran 40 t.ha $^{-1}$ dengan panjang tanaman 10.86 $\mathrm{cm}$. Sedangkan pada panjang tanaman 
umur 14 HST yang paling rendah adalah perlakuan $\left(\mathrm{v}_{0}\right)$ tanpa perlakuan dengan panjang tanaman $14,68 \mathrm{~cm}$ dan panjang tanaman yang tertinggi terdapat pada perlakuan $\left(\mathrm{v}_{4}\right)$ takaran 40 t.ha $^{-1}$ dengan panjang tanaman $16.88 \mathrm{~cm}$. Untuk panjang tanaman umur 21 HST yang terendah terdapat pada perlakuan $\left(\mathrm{v}_{0}\right)$ tanpa perlakuan dengan panjang tanaman 14,68 $\mathrm{cm}$ dan panjang tanaman yang tertinggi adalah perlakuan $\left(\mathrm{v}_{4}\right)$ takaran 40 t.ha $^{-1}$ dengan panjang tanaman $16.88 \mathrm{~cm}$.

Dari Gambar tersebut menunjukkan bahwa semakin besar pemberian perlakuan pupuk vermikompos, maka semakin panjang pula panjang tanaman mentimun yang diperlihatkan.

\section{Jumlah Daun}

Berdasarkan data hasil jumlah daun dan analisis ragam menunjukkan bahwa pemberian berbagai takaran pupuk vermikompos tidak berpengaruh terhadap jumlah daun dari umur 7, 14, dan 21 HST.

Hubungan antara pemberian pupuk vermikompos terhadap jumlah daun umur 7, 14, dan 21 HST disajikan pada Gambar 2.

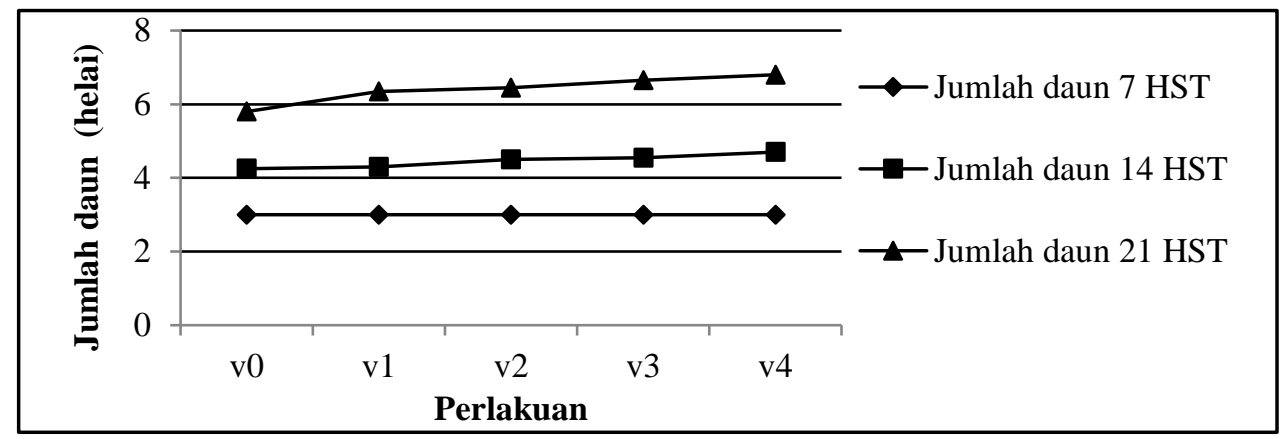

Gambar 2. Grafik hubungan pemberian pupuk vermikompos terhadap peningkatan jumlah daun tanaman mentimun umur 7, 14, dan 21 HST.

Pada Gambar 2 dapat dilihat bahwa jumlah daun umur 7 HST menghasilkan jumlah daun yang sama yaitu 3 helai dan data tidak dapat dianalisis karena tidak memenuhi kaidah statistik. Untuk jumlah daun umur 14 HST yang paling rendah adalah perlakuan ( $\left.\mathrm{v}_{0}\right)$ tanpa perlakuan dengan jumlah daun 4,25 helai dan yang tertinggi terdapat pada perlakuan ( $\left.\mathrm{v}_{4}\right)$ takaran 40 t.ha $^{-1}$ dengan jumlah daun 4,70 helai. Sedangkan jumlah daun umur 21

\section{Diameter Batang}

Berdasarkan hasil analisis ragam menunjukkan bahwa pemberian berbagai takaran pupuk vermikompos tidak berpengaruh terhadap diameter batang umur 7 dan 14 HST tetapi berpengaruh nyata pada umur $21 \mathrm{HST}$. Hasil uji beda nilai tengah diameter batang pada umur 21 HST dapat dilihat pada Tabel 1. Dari Tabel 1 dapat dilihat bahwa pemberian pupuk vermikompos umur 21 HST pada perlakuan $\left(\mathrm{v}_{0}\right)$ tanpa perlakuan
HST yang terendah berada pada perlakuan $\left(\mathrm{v}_{0}\right)$ tanpa perlakuan dengan jumlah daun 5,80 helai dan jumlah daun yang tertinggi adalah perlakuan $\left(\mathrm{v}_{4}\right)$ takaran 40 t.ha $^{-1}$ yaitu 6.80 helai.

Dari Gambar tersebut diperlihatkan bahwa semakin besar pemberian perlakuan pupuk vermikompos, maka semakin banyak pula jumlah daun tanaman mentimun yang diperlihatkan untuk umur 14 dan 21 HST.

menunjukkan diameter batang tanaman mentimun terkecil sebesar 5,00 mm yang berbeda terhadap perlakuan $\left(\mathrm{v}_{4}\right)$ dengan takaran 40 t.ha $^{-1}$ sebesar $6,40 \mathrm{~mm}$ tetapi tidak berbeda terhadap perlakuan $\mathrm{v}_{1}, \mathrm{v}_{2}$, dan v3. Sedangkan pada perlakuan v4 yang merupakan diameter batang tanaman mentimun terbesar dengan $6,40 \mathrm{~mm}$ tidak berbeda terhadap perlakuan $\mathrm{v}_{1}, \mathrm{v}_{2}$, dan $\mathrm{v}_{3}$ tetapi berbeda terhadap perlakuan $\mathrm{v}_{0}$ sebesar 5,00 $\mathrm{mm}$ sehingga diameter batang tanaman mentimun yang paling besar 
terdapat pada perlakuan $\mathrm{v}_{4}$ sebesar 6,40 $\mathrm{mm}$ tetapi untuk mendapatkan hasil diameter batang tanaman mentimun yang efisien dan efektif menggunakan perlakuan (v1) takaran 10 t.ha ${ }^{-1}$ dengan besar 5,60 mm yang merupakan takaran terbaik.

Tabel 1. Hasil uji beda nilai tengah diameter batang pada umur 21 HST .

\begin{tabular}{cc}
\hline Perlakuan & Rata-rata diameter batang \\
\hline $\mathrm{v}_{0}$ & $5,00^{\mathrm{a}}$ \\
$\mathrm{V}_{1}$ & $5,60^{\mathrm{ab}}$ \\
$\mathrm{v}_{2}$ & $5,60^{\mathrm{ab}}$ \\
$\mathrm{v}_{3}$ & $5,80^{\mathrm{ab}}$ \\
$\mathrm{V}_{4}$ & $6,40^{\mathrm{b}}$
\end{tabular}

Keterangan: Angka yang diikuti huruf yang berbeda pada kolom yang sama menunjukkan perlakuan tersebut berbeda berdasarkan uji DMRT pada taraf $5 \%$.

\section{Waktu Berbunga}

Berdasarkan data hasil waktu berbunga dan analisis ragam menunjukkan bahwa perlakuan pemberian berbagai perlakuan pupuk vermikompos berpengaruh nyata terhadap waktu berbunga tanaman mentimun. Hasil uji beda nilai tengah tanaman waktu berbunga dapat dilihat pada Tabel

Tabel 2. Hasil uji beda nilai tengah waktu berbunga tanaman mentimun

\begin{tabular}{cc}
\hline Perlakuan & Rata-rata waktu berbunga (HST) \\
\hline $\mathrm{v}_{0}$ & $32,40^{\mathrm{b}}$ \\
$\mathrm{v}_{1}$ & $30,80^{\mathrm{ab}}$ \\
$\mathrm{v}_{2}$ & $30,00^{\mathrm{ab}}$ \\
$\mathrm{v}_{3}$ & $29,80^{\mathrm{ab}}$ \\
$\mathrm{v}_{4}$ & $28,40^{\mathrm{a}}$ \\
\hline
\end{tabular}

Keterangan: Angka yang diikuti huruf yang berbeda pada kolom yang sama menunjukkan perlakuan tersebut berbeda berdasarkan uji DMRT pada taraf $5 \%$.

Berdasarkan Tabel 2 dapat dilihat bahwa pemberian pupuk vermikompos pada perlakuan $\left(\mathrm{v}_{4}\right)$ takaran $40 \mathrm{t}^{\mathrm{h}} \mathrm{a}^{-1}$ berbeda terhadap perlakuan $\left(\mathrm{v}_{0}\right)$ tanpa perlakuan tetapi tidak berbeda pada perlakuan $\mathrm{v}_{1}, \mathrm{v}_{2}$, dan $v_{3}$. Pada pemberian pupuk vermikompos perlakuan $\mathrm{v}_{4}$ memberikan umur tanaman mentimun waktu berbunga

\section{Jumlah Buah}

Berdasarkan data hasil jumlah buah beserta analisis ragam menunjukkan bahwa perlakuan pemberian berbagai perlakuan pupuk vermikompos berpengaruh nyata terhadap jumlah buah. Hasil uji beda nilai tengah jumlah buah tanaman mentimun dapat dilihat pada Tabel 3 . paling cepat yaitu pada umur 28,40 HST dan untuk tanaman mentimun waktu berbunga paling lambat yaitu pada umur 32,40 HST dengan perlakuan $\mathrm{v}_{0}$ tetapi takaran terbaik untuk waktu berbunga terdapat pada perlakuan $\left(\mathrm{v}_{4}\right)$ takaran 40 t.ha $^{-1}$ pada umur 30,80 HST.

Pada Tabel 3 menunjukkan bahwa pemberian pupuk vermikompos pada perlakuan ( $\left.\mathrm{v}_{4}\right)$ dengan takaran 40 ton.ha ${ }^{-1}$ menghasilkan jumlah buah terbanyak yaitu 8,20 buah yang tidak berbeda dengan $\mathrm{v}_{1}$, $\mathrm{v}_{2}$, dan $\mathrm{v}_{3}$ tetapi berbeda dengan perlakuan $\left(\mathrm{v}_{0}\right)$ tanpa perlakuan sebanyak 5,00 buah 
sehingga perlakuan terbaik untuk jumlah buah tanaman mentimun terdapat pada perlakuan $\left(\mathrm{v}_{1}\right)$ takaran 10 ton.ha ${ }^{-1}$ sebanyak 6,20

buah.

Tabel 3. Hasil uji beda nilai tengah jumlah buah terhadap pemberian pupuk vermikompos.

\begin{tabular}{cc}
\hline Perlakuan & Rata-rata jumlah buah (buah) \\
\hline $\mathrm{v}_{0}$ & $5,00^{\mathrm{a}}$ \\
$\mathrm{v}_{1}$ & $6,20^{\mathrm{ab}}$ \\
$\mathrm{v}_{2}$ & $6,40^{\mathrm{ab}}$ \\
$\mathrm{v}_{3}$ & $6,60^{\mathrm{ab}}$ \\
$\mathrm{v}_{4}$ & $8,20^{\mathrm{b}}$ \\
\hline
\end{tabular}

Keterangan: Nilai rata-rata yang diikuti huruf yang berbeda pada kolom yang sama menunjukkan perlakuan tersebut berbeda berdasarkan uji DMRT pada taraf $5 \%$.

\section{Bobot Basah Buah Pertanaman}

Berdasarkan data hasil bobot basah buah pertanaman beserta analisis ragam menunjukkan bahwa perlakuan pemberian berbagai perlakuan pupuk vermikompos berpengaruh nyata terhadap bobot basah buah pertanaman. Hasil uji beda nilai tengah jumlah buah tanaman mentimun dapat dilihat pada Tabel 4.

Tabel 4. Hasil uji beda nilai tengah bobot basah buah pertanaman terhadap pemberian pupuk vermikompos

\begin{tabular}{cc}
\hline Perlakuan & Rata-rata bobot basah buah $(\mathrm{g})$ \\
\hline $\mathrm{v}_{0}$ & $176,00^{\mathrm{a}}$ \\
$\mathrm{v}_{1}$ & $216,00^{\mathrm{ab}}$ \\
$\mathrm{v}_{2}$ & $248,00^{\mathrm{ab}}$ \\
$\mathrm{v}_{3}$ & $270,00^{\mathrm{ab}}$ \\
$\mathrm{v}_{4}$ & $316,40^{\mathrm{b}}$ \\
\hline
\end{tabular}

Keterangan: Nilai rata-rata yang diikuti huruf yang berbeda pada kolom yang sama menunjukkan perlakuan tersebut berbeda nyata berdasarkan uji DMRT pada taraf $5 \%$.

Dari Tabel 4 terlihat bahwa pemberian pupuk vermikompos pada perlakuan $\left(\mathrm{v}_{4}\right)$ takaran 40 ton.ha $^{-1}$ yang menunjukkan bobot basah buah pertanaman terberat sebesar $316,40 \mathrm{~g}$ yang berbeda nyata terhadap perlakuan $\left(\mathrm{v}_{0}\right)$ tanpa perlakuan dengan berat $176,00 \mathrm{~g}$ tetapi tidak berbeda dengan perlakuan $\mathrm{v}_{1}, \mathrm{v}_{2}$, dan $\mathrm{v}_{3}$ sehingga perlakuan terbaik terdapat pada $\left(\mathrm{v}_{1}\right)$ takaran 10 ton.ha ${ }^{-1}$ seberat $216,00 \mathrm{~g}$.

\section{Pembahasan}

\section{Panjang Tanaman}

Hasil analisis ragam yang menunjukkan bahwa pemberian berbagai perlakuan takaran pupuk vermikompos tidak berpengaruh terhadap panjang tanaman pada umur 7, 14, dan 21 HST. Hal ini kemungkinan disebabkan oleh $\mathrm{C} / \mathrm{N}$ rasio yang tinggi sehingga proses dekomposisinya membutuhkan waktu lebih lama karena secara bertahap - membuat kandungan unsur hara belum tersedia terutama unsur nitrogen. Menurut Golley (1983) dalam Eskawidi, et. al., (2005) bahwa proses dekomposisi melibatkan 2 proses yaitu pengubahan bahan organik dari ukuran yang besar menjadi bagianbagian yang lebih kecil lalu pecahan bahan organik akan direduksi dan dimineralisasi. Hasil dari proses mineralisasi akan melepaskan penyusun bahan organik 
menjadi elemen-elemen kimia yang dapat diserap oleh akar tanaman. Mineralisasi adalah proses konversi bahan organik yaitu nitrogen organik menjadi bentuk sederhana berupa senyawa anorganik seperti ammonium dan nitrat yang dapat diserap tanaman. Proses mineralisasi dilakukan oleh mikroorganisme.

Dari hasil analisis Laboratorium Balai Penelitian Pertanian Lahan Rawa (Ballitra) Banjarbaru (2015) bahwa pada tanah penelitian mengandung unsur hara nitrogen dalam kriteria sangat rendah yaitu $0,165 \%$. Menurut Nurshanti (2009) bahwa kebutuhan unsur nitrogen tercukupi, maka dapat meningkatkan pertumbuhan tanaman. Bila unsur nitrogen tersedia bagi tanaman maka kandungan klorofil pada daun akan meningkat dan proses fotosintesis juga meningkat sehingga asimilat yang dihasilkan lebih banyak, akibatnya pertumbuhan tanaman lebih baik. Maka dengan meningkatnya fotosintesis akan meningkatkan pertumbuhan dan perpanjangan sel, sehingga pertumbuhan tinggi tanaman yang terbentuk semakin tinggi. Apabila tanaman kekurangan unsur hara pertumbuhan tanaman akan terhambat. Keadaan tersebut menyebabkan protein, lemak dan karbohidrat tanaman kurang terbentuk, sehingga dapat mengganggu proses metabolisme, khususnya pembentukan sel-sel baru pada jaringan meristematik tanaman yang pada akhirnya menghambat proses pertumbuhan dan perkembangan tanaman (Lingga, 1991 dalam Tania, et. al., 2013).

\section{Jumlah Daun}

Berdasarkan hasil analisis ragam yang menunjukkan bahwa pemberian perlakuan berbagai takaran pupuk vermikompos tidak berpengaruh terhadap jumlah daun pada umur 7, 14, dan 21 HST.

Hal ini menunjukkan bahwa pemberian perlakuan berbagai takaran pupuk vermikompos belum tersedia kebutuhan unsur haranya terutama unsur nitrogen karena defisiensi hara. Dhani et, al., (2014) menyatakan bahwa metabolisme senyawa organik tanaman akan terganggu jika tanaman mengalami defisiensi unsur hara. Nitrogen merupakan bahan dasar untuk membentuk asam amino dan protein yang akan dimanfaatkan untuk proses metabolisme dari tanaman. Tersedianya $\mathrm{N}$ dalam jumlah yang cukup akan memperlancar metabolisme tanaman dan akhirnya akan mempengaruhi pertumbuhan organ-organ seperti batang, daun dan akar menjadi lebih baik. Akar akan menyerap unsur hara yang diperlukan tanaman dalam bentuk vegetatif sehingga batang tanaman tumbuh tinggi dan akhirnya mempengaruhi jumlah daun dari tanaman (Lakitan, 2001 dalam Dhani, et. al., 2014). Seperti yang diketahui unsur nitrogen pada tanaman berfungsi untuk meningkatkan pertumbuhan daun sehingga daun akan menjadi banyak jumlahnya dan akan menjadi lebar dengan warna yang lebih hijau yang akan meningkatkan kadar protein dalam tubuh tanaman (Nurshanti, 2009).

\section{Diameter Batang}

Berdasarkan hasil analisis ragam yang menunjukkan bahwa pemberian berbagai perlakuan takaran pupuk vermikompos tidak berpengaruh terhadap diameter batang pada umur 7, dan 14 HST tetapi berpengaruh nyata pada umur 21 HST. Hal ini berhubungan erat dengan kandungan unsur hara di dalam tanah yang masih sangat rendah terutama unsur nitrogen, sehingga belum tersedianya kebutuhan unsur hara yang diperlukan bagi pertumbuhan diameter batang umur 7 dan 14 HST. Menurut Suherman (2014) bahwa ketersediaan nitrogen yang cukup akan mampu mendorong pertumbuhan tanaman lebih optimal seperti batang, akar, dan daun.

Sedangkan pada umur 21 HST berdasarkan hasil analisis ragam menunjukkan bahwa pemberian perlakuan berbagai takaran pupuk vermikompos berpengaruh nyata terhadap diameter batang karena hal ini kemungkinan proses dekomposisi bahan organik yang terjadi selama pertumbuhan tanaman oleh mikrobia sehingga kandungan unsur haranya tersedia. Selama masa 
pertumbuhan tanaman terjadi peningkatan aktivitas berbagai macam mikrobia yang sebelumnya tidak terjadi, sehingga dapat menyebabkan kadar nitrogen tanah meningkat. Mikrobia dekomposer memiliki sistem multi enzim yang mampu mengkatalisis penguraian lignin, selulose, ligno- selulose, kitin dan bahan lain dalam bahan organik. Sistem enzim ini tidak mungkin dimiliki oleh satu atau hanya beberapa macam mikrobia, tetapi dimiliki oleh sistem mikrobia yang dapat saja terdiri dari bakteri, cendawan, aktinomisetes dan ragi. Mikrobia tersebut memiliki keragaman sifat seperti aerobik, anaerobik, mikroaerofilik, thermofilik, mesofilik dan sebagainya (Premono, 2003 dalam Eskawidi, et. al., 2005).

Menurut Lingga (2000) dalam Jamilah, et. al., (2013) fungsi utama unsur nitrogen adalah untuk merangsang pertumbuhan tanaman secara keseluruhan, khususnya batang, cabang, dan daun yang berfungsi dalam proses fotosintesis.

\section{Waktu Berbunga}

Berdasarkan data hasil analisis ragam yang menunjukkan bahwa pemberian berbagai perlakuan pupuk vermikompos berpengaruh nyata terhadap waktu berbunga tanaman mentimun. Hal ini kemungkinan disebabkan oleh proses perombakan bahan organik yang sudah terjadi secara sempurna dan kandungan unsur fosfor di dalam tanah yang sudah tersedia dari pemberian pupuk vermikompos dengan nilai $0,443 \%$ yang mempunyai kriteria sangat tinggi berdasarkan Laboratorium Balai Penelitian Pertanian Lahan Rawa, Banjarbaru (2015).

Menurut Lingga (1995) dalam Ayunita, et. al., (2014) bahwa fosfor dapat mempercepat saat munculnya bunga karena salah satu fungsi dari fosfor dalam tanaman yaitu memacu aktivitas fotosintesis. Hasil fotosintesis dirombak melalui respirasi akan menghasilkan asimilat yang sangat dibutuhkan untuk proses pembelahan sel. Menurut Ayunita, et. al., (2014) bahwa adanya peningkatan hasil fotosintesis dan jumlah asimilat maka jumlah dan ukuran sel akan mengalami peningkatan sehingga menyebabkan proses pembungaan cepat terjadi. Selain itu, pupuk vermikompos juga mengandung hormon tumbuh giberelin yang dapat merangsang terjadinya pembungaan sehingga dengan adanya pemberian vermikompos tanaman lebih cepat berbunga dibandingkan tanpa pemberian vermikompos.

\section{Jumlah Buah}

Berdasarkan data hasil analisis ragam yang menunjukkan bahwa pemberian berbagai perlakuan pupuk vermikompos berpengaruh nyata terhadap jumlah buah tanaman mentimun. Hal ini menunjukkan bahwa pemberian pupuk vermikompos dapat memenuhi kebutuhan hara tanaman mentimun sampai pada fase generatif terutama unsur fosfor dengan kriteria sangat tinggi pada nilai $0,433 \%$ berdasarkan Laboratorium Balai Penelitian Pertanian Lahan Rawa, Banjarbaru (2015)

Nyakpa, et. al.,(1988) dalam Ayunita, et. al., (2014) menyatakan bahwa unsur fosfor mempengaruhi pembelahan sel dan pembentukan lemak, bunga, buah dan biji. Unsur fosfor yang tersedia merupakan sumber energi bagi setiap sel tanaman dalam jaringan tanaman sehingga proses fotosintesis dan metabolisme berjalan dengan baik. Dengan demikian pembentukan asam amino dan protein untuk pembentukan sel-sel baru terjadi, apabila laju pertumbuhan sel berjalan dengan cepat maka pertumbuhan batang, akar dan daun akan berjalan dengan cepat. Sesuai menurut Ayunita, et. al., (2014) bahwa proses pembentukan sel-sel baru tersebut akan mempengaruhi cepat masaknya buah, sehingga mempercepat umur panen pada suatu tanaman.

\section{Bobot Basah Buah Pertanaman}

Berdasarkan data hasil analisis ragam yang menunjukkan bahwa pemberian berbagai perlakuan pupuk vermikompos berpengaruh sangat nyata terhadap bobot basah buah pertanaman. Hal ini menunjukkan bahwa pemberian berbgai perlakuan pupuk vermikompos dapat memenuhi kebutuhan unsur hara tanaman mentimun sampai pada fase 
generatif terutama unsur hara nitrogen, fosfor, dan kalium.

Menurut Ayunita, et. al., (2014) bahwa tanaman saat memasuki fase generatif sangat memerlukan tambahan unsur-unsur hara esensial diantaranya nitrogen, fosfor dan kalium. Unsur-unsur tersebut diserap oleh tanaman dan digunakan untuk proses metabolisme di dalam tanaman tersebut. Suplai hara yang cukup membantu terjadinya proses fotosintesis dalam tanaman menghasilkan senyawa organik yang akan diubah dalam bentuk adenosine triphosphate (ATP) saat berlangsungnya respirasi, selanjutnya adenosine triphosphate (ATP) ini digunakan untuk membantu pertumbuhan tanaman. Selama pertumbuhan reproduktif akan terjadi pemacuan pembentukan bunga, polong serta biji. Ditambahkan Nyakpa, et. al., (1988) dalam Ayunita, et. al., (2014) bahwa unsur fosfor mempengaruhi pembelahan sel dan pembentukan lemak, bunga, buah dan biji. Ketersediaan unsur hara yang seimbang dalam tanah, sehingga mempengaruhi pertumbuhan vegetatif dan generatif tanaman, khususnya berat buah (Suherman, 2014).

\section{KESIMPULAN}

Diketahui pemberian berbagai takaran pupuk vermikompos berpengaruh nyata terhadap diameter batang umur 21 HST, waktu berbunga, jumlah buah mentimun, dan berpengaruh sangat nyata pada bobot basah buah mentimun tetapi tidak berpengaruh terhadap pada panjang tanaman umur 7 HST sampai 21 HST, jumlah daun umur 7 HST sampai 21 HST, diameter batang umur 7 HST dan 14 HST. Terdapat perlakuan takaran vermikompos terbaik untuk tanaman mentimun adalah (v1) 10 t.ha $^{-1}$.

\section{DAFTAR PUSTAKA}

Ayunita, I. Mansyoer, A. \& Sampoerno. (2014). Uji Beberapa Dosis Pupuk Vermikompos pada Tanaman Kacang Hijau (Vigna radiata L.).
Jom Faperta Universitas Riau. 1 (2).

Dhani, H. Wardati, dan Rosmimi. (2014). Pengaruh Pupuk Vermikompos Pada Tanah Inceptisol Terhadap Pertumbuhan dan Hasil Sawi Hijau (Brassica juncea L.). Jom Faperta Universitas Riau, 1(1).

Eskawidi, M. R. Endang, A dan Solichatun. (2005). Pengaruh vermikompos terhadap kadar nitrogen tanah, aktivitas nitrat reduktase dan pertumbuhan caisin (Brassica rapa L.). Biosmart, 7(1), 32-36.

Fahrudin, F. (2009). Budidaya Caisim (Brassica Juncea L.) Menggunakan Ekstrak Teh dan Pupuk Kascing (Tesis). Surakarta: Program Studi Agronomi Fakultas Pertanian Universitas Sebelas Maret.

Hanafiah, A. K. (2002). Rancangan Percobaan. . Jakarta: PT. Raja Grafindo Persada.

Jamilah, Rahayuni, T., dan Susana, R. (2013). Pengaruh Pemberian Kascing terhadap Pertumbuhan Bibit Kakao pada Tanah Podsolik Merah Kuning. Jurnal Sains Mahasiswa Pertanian 2(2).

Kusumawati, N. (2011). Evaluasi Perubahan Temperatur, $\mathrm{Ph}$ dan Kelembaban Media pada Pembuatan Vermikompos dari Campuran Jerami Padi dan Kotoran Sapi Menggunakan Lumbricus Rubellus. Jurnal Inotek, 15(1), 4556.

Nurshanti, D. F. (2009). Pengaruh pemberian pupuk organik terhadap pertumbuhan dan hasil tanaman sawi Caisim (Brassica Juncea L.). Jurnal Agrotekbis, 1(1), 1-7. 
Laboratorium Balai Penelitian Pertanian Lahan Rawa (Balittra). 2015. Hasil analisis tanah Desa Teluk Mesjid Kecamatan Haruyan Kabupaten Hulu Sungai Tengah. Banjarbaru: Balai Penelitian Lahan Rawa.

Rukmana, R. (1994). Budidaya Mentimun. Yogyakarta: Kanisius.

Suherman. (2014). Pengaruh Dosis Pupuk Kandang Sapi dan Konsentrasi Gandasil B terhadap Pertumbuhan dan Produksi Tanaman Mentimun (Cucumis sativus L.)(Skripsi).
Padang : Fakultas Pertanian Jurusan Agroteknologi Universitas Tamansiswa Padang.

Tania, N. Astina dan Setia Budi. (2012). Pengaruh pemberian pupuk hayati terhadap pertumbuhan dan hasil jagung semi pada tanah podsolik merah kuning. Jurnal Sains Mahasiswa Pertanian, 1(1), 10-15.

Wijoyo, M. P. (2012). Budi Daya Mentimun Yang Lebih Menguntungkan. Jakarta: Pustaka Agro Indonesia. 